\title{
Peningkatan Prestasi Belajar Matematika Siswa Kelas IV SD 4 Adiwarno Melalui Metode Guided Discovery Learning
}

\author{
Mamik Junianti \\ SD 4 Adiwarno \\ mamikjunianti2203@gmail.com
}

\section{Article History}

received 3/12/2020

\begin{abstract}
research was motivated by the problem of the low learning outcomes of fourth grade mathematics. This is because mathematics learning is still teacher centered or still dominated by teachers, teachers tend to still teach mathematics in an abstract/symbolic way where the learning method is contrary to the cognitive development of students. This study aims to determine whether there is an increase in mathematics learning outcomes using the Guided Discovery Learning method in fourth grade students of SD 4 Adiwarno. The research was conducted in March-April 2020 in the fourth grade of SD 4 Adiwarno, Mejobo District, Kudus Regency as the research subject. The results of the study showed that the results of learning mathematics in the initial conditions were only $33.33 \%$ of students who reached the KKM. There was an increase in the first cycle of learning outcomes to $50 \%$ of students and in the second cycle increased to $94.4 \%$ of students who reached the KKM. The author suggests elementary school teachers to apply the Guided Discovery Learning method in learning mathematics in order to improve student achievement.
\end{abstract}

Keywords: learning outcomes, mathematics, guided discovery learning method

\begin{abstract}
Abstrak
Penelitian dilatarbelakangi oleh permasalahan rendahnya hasil belajar matematika kelas IV. Hal ini dikarenakan pembelajaran matematika yang masih teacher centered atau masih didominasi guru, guru cenderung masih mengajarkan matematika secara abstrak/simbolis dimana metode pembelajaran tersebut bertentangan dengan perkembangan kognitif peserta didik. Penelitian bertujuan untuk mengetahui ada tidaknya peningkatan hasil belajar matematika menggunakan metode Guided Discovery Learning pada peserta didik kelas IV SD 4 Adiwarno. Penelitian yang dilaksanakan pada bulan Maret-April 2020 di kelas IV SD 4 Adiwarno Kecamatan Mejobo Kabupaten Kudus sebagai subjek penelitian. Hasil penelitian menunjukkan hasil belajar matematika pada kondisi awal hanya $33,33 \%$ peserta didik yang mencapai KKM. Terjadi peningkatan pada siklus I hasil belajar menjadi $50 \%$ peserta didik dan pada siklus II meningkat menjadi $94,4 \%$ peserta didik yang mencapai KKM. Penulis menyarankan guru sekolah dasar untuk menerapkan metode Guided Discovery Learning dalam pembelajaran matematika agar dapat meningkatkan prestasi belajar siswa.
\end{abstract}

Kata kunci: hasil belajar, matematika, metode guided discovery learning $\begin{array}{lr}\text { Social, Humanities, and Education Studies (SHEs): Conference Series } & \text { p-ISSN 2620-9284 } \\ \text { https://jurnal.uns.ac.id/shes } & \text { e-ISSN 2620-9292 }\end{array}$ 


\section{PENDAHULUAN}

Pendidikan dasar merupakan jenjang pendidikan yang melandasi jenjang pendidikan menengah (Undang-undang Nomor 20 Tahun 2003, pasal 17). Masalah utama dalam pembelajaran pada pendidikan formal (sekolah) adalah masih rendahnya daya serap siswa (Trianto, 2009: 5). Usaha keras telah dilaksanakan melalui berbagai pembaharuan agar matematika yang diajarkan dapat merangsang siswa untuk mencari sendiri, melakukan penyelidikan sendiri, melakukan pembuktian terhadap dugaan yang telah mereka buat sendiri, dan mencari tahu jawaban atas pertanyaan yang ada (Turmudi, 2009: 1).

Berdasarkan observasi, dokumentasi, dan diskusi yang dilakukan peneliti dengan guru kelas IV SD 4 adiwarnopada tanggal 9 Maret 2018 terungkap beberapa masalah yang terjadi dalam pembelajaran matematika khususnya pada materi jaring-jaring balok dan kubus, yaitu: (1) siswa takut mencoba membuat jaring-jaring balok dan kubus karena takut salah, (2) pembelajaran masih terpusat pada guru yakni: guru menerangkan serta menggambarkan di papan tulis dan siswa mendengaran serta menggambar dibuku tulis masing-masing, dan (3) kurang melibatkan siswa dalam proses pembelajaran. Masalah tersebut menyebabkan prestasi belajar matematika siswa rendah. Hal ini terbukti dari hasil belajar matematika siswa pada semester 1 dari 18 siswa hanya 33,3 \% (6 siswa) yang tuntas belajar, sedangkan 66,7\% (12 siswa) belum memenuhi Kriteria Ketuntasan Minimal (KKM) matematika yaitu 62.

Belajar dapat dipahami sebagai tahapan perubahan seluruh tingkah laku individu yang relatif menetap sebagai hasil pengalaman dan interaksi dengan lingkungan yang melibatan proses kognitif (Syah, 2010: 90). Belajar merupakan suatu proses perubahan perilaku sebagai hasil pengalaman individu pelaku proses pembelajaran saat berinteraksi dengan lingkungannya yang dilakukan secara sadar (Markaban, 2008: 8). Ini berarti pembelajaran merupakan upaya membuat seseorang belajar tentang sesuatu hal.

Prestasi belajar memiliki makna yang sama dengan hasil belajar. Hasil belajar adalah perubahan perilaku yang terjadi setelah mengikuti proses belajar mengajar sesuai dengan tujuan pendidikan (Purwanto, 2011: 54). Demikian pula hasil belajar merupakan pencapaian sejauh mana tujuan-tujuan instruksional telah dapat dicapai atau dikuasai oleh siswa dalam bentuk tingkah laku yang diperlihatkannya setelah mereka menempuh pengalaman belajarnya atau proses belajar mengajar (Sudjana, 2011: 2). Prestasi/hasil belajar adalah perubahan perilaku baik pengetahuan, keterampilan atau sikap seorang akibat usaha dalam proses belajar mengajar yang dilakukan sehingga mencapai tujuan pendidikan yang diinginkan.

Matematika berasal dari bahasa Yunani, yaitu mathẽmatiká yang artinya pengertian pola, struktur, perubahan, ruang, penelitian bilangan dan angka". Pengertian matematika sangat sulit didefinisikan secara akurat (Septiasari, 2011:28). Pembelajaran matematika adalah proses pemberian pengalaman belajar kepada peserta didik melalui serangkaian kegiatan yang terencana sehingga peserta didik memperoleh kompetensi tentang bahan matematika yang dipelajari (Muhsetyo, 2008: 1.26). Matematika merupakan suatu bidang ilmu yang merupakan alat pikir, berkomunikasi, memecahkan berbagai persoalan praktis, yang unsur-unsurnya adalah logika dan intuisi, analisis dan konstruksi, generalitas dan individualitas, serta mempunyai cabang-cabang antara lain aritmatika, aljabar, geometri dan analisis (Uno, 2009: 129). Hakikat belajar matematika adalah suatu aktifitas mental untuk memahami arti dan hubungan-hubungan serta simbol-simbol, kemudian diterapkannya pada situasi nyata.

Pembelajaran matematika siswa SD berbeda dengan pembelajaran matematika siswa sekolah lanjutan. Karena pelaksanaan pembelajarannya harus sesuai dengan tahap perkembangan intelektual siswa secara teratur dan sesuai dengan perkembangan umurnya. Jean Piaget mengemukakan proses anak sampai mampu berfikir seperti orang dewasa melalui empat tahap perkembangan, yaitu: Tahap sensori motor (usia 0 sampai 
2 th), Tahap praoperasional (usia 2 sampai 7 th), Tahap operasional kongrit (usia 7 sampai 11 th), Tahap operasional formal (usia 11 sampai 15 th) (Sumantri, 2008: 1.15). Dari tahap perkembangan berfikir anak menurut Jean Piaget di atas menunjukkan bahwa siswa SD tergolong ke dalam tahap operasional kongkrit. Sehingga dalam belajar siswa memerlukan bantuan benda kongkrit supaya dapat memahami operasi logis. Dengan demikian pelaksanaan pembelajaran di SD sepatutnya memperhatikan tahap perkembangan berfikir siswa agar tujuan dalam pembelajaran matematika yang dilakukan dapat tercapai dan berjalan secara efektif.

Salah satu metode alternatif yang dapat digunakan adalah metode pembelajaran Guided discovery Learning. Metode Guided discovery Learning menekankan aktivitas siswa dalam belajar dan didampingi guru sebagai petunjuk pembelajaran agar siswa bekerja lebih terarah dalam rangka mencapai tujuan yang ditetapkan (Kanzunnudin, 2011: 14). Discovery merupakan salah satu metode yang memungkinkan para anak didik terlibat langsung dalam kegiatan belajar-mengajar, sehingga mampu menggunakan proses mentalnya untuk menemukan suatu konsep atau teori yang sedang dipelajari (Takdir, 2012: 33). Mengajar dengan discovery selain berkaitan dengan penemuan juga bisa meningkatkan kemampuan berpikir kreatif (Rohim, 2012; 40). Model pembelajaran discovery merupakan kegiatan pembelajaran yang melibatkan secara maksimal seluruh kemampuan siswa untuk mencari dan menemukan sesuatu (benda, manusia, atau peristiwa) secara sistematis, kritis, logis, analitis sehingga mereka dapat merumuskan sendiri penemuannya dengan penuh percaya diri.

Keberhasilan metode pembelajaran sudah dibuktikan oleh Linda Priyanti (2011) dalam penelitiannya yang berjudul Peningkatan hasil belajar matematika luas bangun datar siswa kelas V SDN 01 Lorejo Kabupaten Blitar melalui model penemuan terbimbing (Guide Discovery), menunjukkan hasil bahwa penggunan metode Guided Discovery Learning (GDL) atau penemuan terbimbing dapat meningkatkan hasil belajar siswa. Prosentase ketuntasan beajar siswa pada pra tindakan adalah $21,4 \%$, pada siklus I pertemuan I 36\%, siklus I pertemuan 2 67\%, pada siklus II pertemuan 192,8\% dan pada siklus II pertemuan 2 100\% mencapai KKM.

Berdasarkan latar belakang, maka peneliti merumuskan masalah penelitian yaitu Apakah terdapat peningkatan prestasi belajar matematika peserta didik kelas IV Semester 2 SD 4 Adiwarno materi jaring-jaring balok dan kubus menggunakan metode Guided Discovery Learning Tahun 2018/2019.

Tujuan penelitian ini adalah untuk mengetahui apakah melalui penerapan metode Guided Discovery Learning pada peserta didik kelas IV Semester 2 SD 4 Adiwarno materi jaring-jaring balok dan kubus prestasi peserta didik dapat meningkat.

\section{METODE}

Jenis penelitian yang dilakukan merupakan Penelitian Tindakan Kelas (PTK) atau Classroom Action Research (CAR). Penelitian Tindakan Kelas (PTK) yaitu suatu bentuk penelitiam yang dilaksanakan untuk memecahkan masalah yang dihadapi dalam pelaksanaan proses pembelajaran (Suranto, 2010: 10). Tindakan tersebut dilakukan oleh guru atau dengan arahan dari guru yang dilakukan oleh peserta didik (Arikunto, 2012:3). Penelitian Tindakan Kelas ini dilaksanakan di kelas IV SD 4 Adiwarno Kecamatan Mejobo Kabupaten Kudus Semester II Tahun Pelajaran 2018/2019. Penelitian dilaksanakan selama 2 bulan yaitu dari bulan Maret sampai dengan bulan April 2020.

Subyek penelitian yaitu peserta didik kelas IV SD 4 Adiwarno Desa Hadiwarno Kecamatan Mejobo Kabupaten Kudus. Peserta didik kelas IV SD 4 Adiwarno berjumlah 18 peserta dengan kemampuan yang heterogen serta memiliki hasil belajar yang rendah pada mata pelajaran matematika.

Penelitian ini menggunakan model Kemmis yang dikembangkan oleh Stephen Kemmis dan Roin Mc Taggart. Model ini meliputi tahapan perencanaan (planning), 
tindakan (action) dan observasi (observation), dan refleksi (reflection) yang saling terkait satu sama lain. Kemudian diikuti dengan perencanaan ulang yang dilaksanakan dalam bentuk siklus tersendiri (Zainal, 2011:22). Teknik pengumpulan data dilakukan dengan cara observasi (dilakukan selama proses pembelajaran), tes (dilaksanakan pada akhir pembelajaran setiap siklus), dan dokumentasi (melihat situasi pada saat proses pembelajaran) (Sugiyono, 2013: 329).

\section{HASIL DAN PEMBAHASAN}

Penelitian berfokus pada perbaikan untuk meningkatkan hasil belajar matematika khususnya pada aspek kognitif, peserta didik kelas IV SD 4 Adiwarno dengan menggunakan metode pembelajaran Guided Discovery Learning. Pembelajaran dengan menggunakan metode pembelajaran dengan model penemuan terbimbing dapat berjalan dengan efekif dalam pembelajaran matematika di kelas maka, guru wajib memahami dengan benar langkah-langkah model penemuan terbimbing ini. Langkahlangkah penemuan terbimbing adalah sebagai berikut:

1) Merumuskan masalah yang akan diberikan kepada siswa dengan data secukupnya. Perumusannya harus jelas dan hindari pernyataan yang menimbulkan salah tafsir agar arah yang ditempuh siswa tidak salah.

2) Dari data yang diberikan guru, siswa menyusun, memproses, mengorganisir, dan menganalisis data tersebut. Dalam hal ini, bimbingan guru dapat diberikan sejauh yang diperlukan saja. Bimbingan ini sebaiknya mengarahkan siswa untuk melangkah kearah yang hendak dituju, melalui pertanyaan-pertanyaan atau LKS (Lembar Kerja Siswa).

3) Siswa menyusun konjektur (prakiraan) dari hasil analisis yang dilakukan.

4) Bila dipandang perlu, konjektur yang telah dibuat siswa tersebut di atas diperiksa oleh guru. Hal ini penting dilakukan untuk meyakinkan kebenaran prakiraan siswa, sehingga akan menuju arah yang hendak dicapai.

5) Apabila telah diperoleh kepastian tentang kebenaran konjektur tersebut, maka verbalisasi konjektur sebaiknya diserahkan juga kepada siswa untuk menyusunnya. Di samping itu perlu diingat pula bahwa induksi tidak menjamin $100 \%$ kebenaran konjektur.

6) Sesudah siswa menemukan apa yang dicari, hendaknya guru menyediakan soal latihan atau soal tambahan untuk memeriksa apakah hasil penemuan itu benar (Markaban, 2008: 17).

Berdasarkan pendapat ahli pendidikan di atas, maka peneliti membagi langkahlangkah pembelajaran menggunakan metode Guided Discovery Learning kedalam lima tahapan pembelajaran.

1) Tahap I Orientasi pada masalah.

2) Tahap II Menganalisis data.

3) Tahap III Eksperimen.

4) Tahap IV Menyusun konjektur

5) Tahap V Menganalisis proses.

Setiap model pembelajaran disamping mempunyai kelebihan-kelebihan yang dimilikinya pasti tersimpan beberapa kekurangan di dalamnya. Sebagai suatu model pembelajaran, penemuan terbimbing juga memiliki kelebihan dan kekurangan. Kelebihan dan kekurangan dari metode penemuan terbimbing adalah sebagai berikut:

1) Siswa dapat berpartisipasi aktif dalam pembelajaran yang disajikan.

2) Menumbuhkan sekaligus menanamkan sikap inquiry (mencari-temukan)

3) Mendukung kemampuan problem solving siswa.

4) Memberikan wahana interaksi antar siswa, maupun siswa dengan guru, dengan demikian siswa juga terlatih untuk menggunakan bahasa Indonesia yang baik dan benar. 
5) Materi yang dipelajari dapat mencapai tingkat kemampuan yang tinggi dan lebih lama membekas karena siswa dilibatkan dalam proses menemukanya.

Sementara itu kekurangannya adalah sebagai berikut:

1) Untuk materi tertentu, waktu yang tersita lebih lama.

2) Tidak semua siswa dapat mengikuti pelajaran dengan cara ini. Dilapangan, beberapa siswa masih terbiasa dan mudah mengerti dengan model ceramah.

3) Tidak semua topik cocok disampaikan dengan model ini. Umumnya topik-topik yang berhubungan dengan prinsip dapat dikembangkan dengan Model Penemuan Terbimbing (Hariyadi, 2009: 5).

Tabel 1. Perbandingan Ketuntasan Hasil Belajar Matematika Peserta didik Kondisi Awal, Siklus I, dan Siklus II

\begin{tabular}{cccccccc}
\hline & & \multicolumn{2}{c}{ Kondisi Awal } & \multicolumn{2}{c}{ Siklus I } & \multicolumn{2}{c}{ Siklus II } \\
\cline { 3 - 8 } No Nilai & $\begin{array}{c}\text { Jumlah } \\
\begin{array}{c}\text { Peserta } \\
\text { didik }\end{array}\end{array}$ & $\begin{array}{c}\text { Prosentase } \\
(\%)\end{array}$ & $\begin{array}{c}\text { Jumlah } \\
\text { Peserta } \\
\text { didik }\end{array}$ & $\begin{array}{c}\text { Prosentase } \\
(\%)\end{array}$ & $\begin{array}{c}\text { Jumlah } \\
\text { Peserta } \\
\text { didik }\end{array}$ & $\begin{array}{c}\text { Prosentase } \\
(\%)\end{array}$ \\
\hline 1 & $<62$ & 12 & 66,67 & 9 & 50 & 1 & 5,6 \\
2 & $\geq 62$ & 6 & 33,33 & 9 & 50 & 17 & 94,4 \\
\multicolumn{2}{c}{\begin{tabular}{l} 
Jumlah \\
\hline
\end{tabular}} & 18 & 100 & 18 & 100 & 18 & 100 \\
\hline
\end{tabular}

Berdasarkan tabel di atas dapat dilihat bahwa pada kondisi awal yang tuntas hasil belajar hanya 6 peserta didik atau sebesar 33,33\% dan yang belum tuntas sebanyak 12 peserta didik atau sebesar $66,67 \%$ dengan nilai rata-rata 60,2 . Pada siklus I diketahui bahwa setelah dilakukan evaluasi, peserta didik yang sudah tuntas belajar atau mendapat nilai di atas KKM ( $\geq 62$ ) sebanyak $9(50 \%)$ peserta didik. Peserta didik yang belum tuntas belajar atau dibawah KKM $(<62)$ sebanyak $9(50 \%)$ peserta didik. Nilai tertinggi pada siklus I adalah 97, terendah 26 , dan rata-rata nilai kelas 63,4 . Peserta didik yang sudah tuntas diberikan pengayaan, sedangkan yang belum tuntas diberi remidial. Peningkatan yang terjadi sebesar $16,67 \%$. Meskipun demikian, peningkatan hasil belajar ini belum mencapai kriteria yang ditetapkan peneliti yaitu $75 \%$ dari jumlah peserta didik.

Penelitian dilanjutkan ke siklus II dengan memperbaiki dan lebih mengoptimalkan pembelajaran sesuai dengan hasil refleksi. Perbaikan tersebut diantaranya memaksimalkan pengarahan dalam setiap kegiatan yang dilakukan peserta didik. Memperhatikan setiap kegiatan belajar peserta didik dalam kelompok apakah sudah sesuai petunjuk apa belum. Memberi bimbingan pada semua kelompok dan bimbingan ekstra pada anggota kelompok yang belum bisa mengikuti pembelajaran dengan baik. Selalu mengecek pengetahuan peserta didik, apakah sudah faham dengan materi yang dipelajarai.

Kondisi ini berubah setelah dilakukan tindakan pada Siklus II, diperoleh data bahwa 1 (5,6\%) peserta didik memperoleh nilai dibawah KKM dan 17 (94,4\%) peserta didik memperoleh nilai yang memenuhi KKM dengan nilai tertinggi 100 dan nilai terendah 46. Hasil tes evaluasi peserta didik pada siklus II sudah mencapai target peneliti, yaitu minimal $75 \%$ atau 15 peserta didik memperoleh nilai yang memenuhi KKM. Peserta didik yang sudah tuntas diberikan pengayaan, sedangkan yang belum tuntas diberi remidial.

Adanya peningkatan pada hasil belajar matematika peserta didik. Pada kondisi awal, peserta didik yang mencapai ketuntasan hanya sebesar $33,3 \%$, pada siklus I peserta didik yang mencapai ketuntasan sebesar $50 \%$, dan pada siklus II peserta didik yang mencapai ketuntasan sebanyak sebesar $94,4 \%$. Terjadi peningkatan sebesar $16,67 \%$ pada siklus I dari kondisi awal dan peningkatan sebesar $44,4 \%$ pada siklus II dari siklus I. Sedangkan peningkatan yang terjadi dari kondisi awal ke siklus II sebesar 
$61,07 \%$. Peningkatan hasil belajar ini sudah mencapai kriteria yang ditetapkan peneliti yaitu $75 \%$ dari jumlah peserta didik.

Hasil penelitian tindakan kelas ini, juga sejalan dengan penelitian yang telah dilaksanakan oleh Linda Priyanti (2011) dalam penelitiannya yang berjudul Peningkatan hasil belajar matematika luas bangun datar siswa kelas V SDN 01 Lorejo Kabupaten Blitar melalui model penemuan terbimbing (Guide Discovery), menunjukkan hasil bahwa penggunan metode Guided Discovery Learning (GDL) atau penemuan terbimbing dapat meningkatkan hasil belajar siswa. Prosentase ketuntasan beajar siswa pada pra tindakan adalah $21,4 \%$, pada siklus I pertemuan I 36\%, siklus I pertemuan $267 \%$, pada siklus II pertemuan $192,8 \%$ dan pada siklus II pertemuan 2 100\% mencapai KKM. Berdasarkan pada hasil penelitian yang dilakukan penulis dalam pembelajaran matematika dengan menerapkan metode Guided Discovery Learning mampu meningkatkan prestasi belajar peserta didik kelas IV SD 4 Adiwarno Semester II Tahun Pelajaran 2018/2019.

Hal ini dapat membuktikan bahwa metode pembelajaran matematika dengan menerapkan metode Guided Discovery Learning mampu meningkatkan prestasi belajar peserta didik kelas IV SD 4 Adiwarno Kecamatan Mejobo Kabupaten Kudus.

\section{SIMPULAN}

Setelah dilakukan tindakan dapat disimpulkan bahwa pembelajaran matematika dengan menerapkan metode Guided Discovery Learning mampu meningkatkan prestasi belajar peserta didik. Hal itu dibuktikan dengan meningkatnya prosentase ketuntasan belajar peserta didik dan nilai rata-rata kelas. Persentase ketuntasan belajar peserta didik pra siklus $33,3 \%$, pada siklus I $50 \%$ atau naik sebesar $16,7 \%$, pada siklus II $94,4 \%$ atau naik sebesar $44,4 \%$. Dari hasil penelitian yang peniliti laksanakan, maka hipotesis penelitian ini terbukti dapat meningkatkan prestasi belajar peserta didik kelas IV SD 4 Adiwarno tahun pelajaran 2018/2019.

Implikasi teoritis penelitian ini yaitu dapat dijadikan sebagai perbaikan metode pembelajaran di sekolah tentang pengembangan metode pembelajaran Guided Discovery Learning, sebagai metode untuk meningkatkan hasil belajar peserta didik dalam pembelajaran matematika. Selain itu, dapat dijadikan sebagai dasar bertindak bagi pendidik dan dunia kependidikan pada umumnya.

Implikasi praktis yang diperoleh dari penelitian ini bagi guru/peneliti, sebagai tambahan pengetahuan mengenai metode pembelajaran Guided Discovery Learning dan mengembangkan proses pembelajaran di kelas. Bagi peserta didik,pembelajaran dengan metode Guided Discovery Learning dapat dapat meningkatkan pemahaman siswa dalam materi menentukan jaring-jaring balok dan kubus serta meningkatkan prestasi belajar peserta didik. Bagi sekolah, dapat digunakan untuk pengambilan kebijakan yang mendukung pelaksanaan pembelajaran di SD khususnya dalam memilih metode pembelajaran yang tepat untuk meningkatkan prestasi belajar siswa.

\section{DAFTAR PUSTAKA}

Arikunto, S. 2012. Penelitian Tindakan Kelas. Jakarta: Bumi Aksara

Hariyadi, Ahmad. 2009. Model Pembelajaran Penemuan Terbimbing Keliling Daan Luas Daerah Bangun Datar. Surabaya: PT. JePe Press Media Utama

Kanzunnudin M, Zuliana, dan Bintoro. 2011. Keefektifan Metode Guided Discovery Learning Berbantuan Lembar Kegiatan Siswa Dalam Pembelajaran Matematika SD Materi Geometri. PTK, Universitas Muria Kudus: Kudus

Markaban. 2008. Model Penemuan Terbimbing pada Pembelajaran Matematika SMK. Yogyakarta: Pusat Pengembangan dan Pemberdayaan Pendidik dan Tenaga Kependidikan Matematika

Muhsetyo, Gatot. Dkk. 2008. Pembelajaran Matematika SD. Jakarta: Universitas Terbuka 
Purwanto. 2011. Evaluasi Hasil Belajar. Yogyakarta: Pustaka Belajar

Rohim, Fatur. dkk. 2012. Penerapan Model Discovery Terbimbing pada pembelajaran Fisika Untuk Meningkatkan Kemampuan Berpikir Kreatif. Unnes Physics Education Journal. Vol. 1 No. 1 (2012)

Septisari, Andini. 2011. Ensiklopedia Matematika (K-Q). bandung: PT Indahjaya Adipratama

Sudjana, Nana. 2011. Penilaian Hasil Proses Belajar Mengajar. Bandung: PT Remaja Rosdakarya

Sugiyono. 2013. Metode Penelitian Pendidikan. Bandung: Alfabeta

Sumantri, mulyani, dan Syaodih, Nana. 2008. Perkembangan Peserta Didik. Jakarta: Universitas Terbuka

Suranto, Sukidin, dan Basrowi. 2010. Manajemen Penelitian Tindakan Kelas. Jakarta: Insan Cendekia

Syah, Muhibbin. 2010. Psikologi Pendidikan. Bandung: PT Remaja Rosdakarya

Takdir, Mohammad Ilahi. 2012. Pembelajaran Discovery Strategy dan Mental Vocational Skill. Yogyakarta: DIVA Press

Trianto. 2009. Mendesain Model Pembelajaran Inovatif-Progresif; Konsep, Landasan dan Implementasinya pada Kurikulum Tingkat Satuan Pendidikan (KTSP). Jakarta: Kencana

Turmudi. 2009. Landasan Filosofis dan Teoritis Pembelajaran Matematika (Paradigma Eksploratif dan Investigatif). Jakarta: PT. Leuser Cita Pustaka

Undang-undang Republik Indonesia. 2003. Nomor 20 Tahun 2003 Tentang Sitem Pendidikan nasional. Bandung: Citra Umbara

Uno. Hamzah B. 2009. Model Pembelajaran; Menciptakan Proses Belajar Mengajar yang Kreatif dan Efektif. Jakarta: Bumi Aksara

Zainal, A. 2011. Penelitian Tindakan Kelas. Bandung: Yrama Widya 